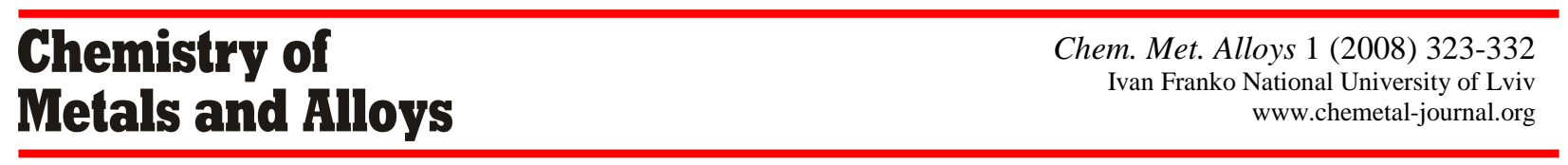

\title{
Phase transformations in Ag70.5Cu26.5Ti3 filler alloy during brazing processes
}

\author{
Sviatoslav HIRNYJ ${ }^{1} *$, J. Ernesto INDACOCHEA ${ }^{2}$ \\ ${ }^{1}$ Department of AE Diagnostics of Materials, Karpenko Physico-Mechanical Institute, \\ Naukova St. 5, 79601 Lviv, Ukraine \\ ${ }^{2}$ Department of Civil and Materials Engineering, University of Illinois at Chicago, \\ 842 W. Taylor Street, 60607 Chicago, Illinois, U.S.A \\ * Corresponding author. Tel.: +380-32-2296351; fax: +380-32-2649427; e-mail: hirnyj@ipm.lviv.ua
}

Received October 13, 2008; accepted November 28, 2008; available on-line March 19, 2009

\begin{abstract}
Phase transformations that occur in the brazing alloy Ag70.5Cu26.5Ti3 are described. The liquid segregation paths and the liquid composition path are presented. The evolution of the liquid and the concentration of titanium in the liquid are plotted versus temperature. With increasing temperature the activity of titanium in the liquid increases and is sufficient for reactive brazing even before the alloy is completely melted and liquid is segregated. In the liquid, copper suppresses the activity of titanium while silver enhances it. The activities of titanium in both segregated liquids are identical, though the concentrations are very different. Thus, both liquids - Ag-Cu-rich $\mathrm{L} 1$ and $\mathrm{Cu}$-Ti-rich $\mathrm{L} 2$ - are equally reactive and responsible for wetting and spreading, not just L2, as often believed. The major differences (including gravimetric) between L1 and L2 and the effect of preferential segregation of Ag to the free surface of the liquid on surface tension are discussed.
\end{abstract}

Silver-copper eutectic / Titanium / Active filler metal / Reactive brazing / Segregation / Phase diagram

\section{Introduction}

Ag-Cu near-eutectic alloys modified with such a reactive metal as titanium have been known for some time as filler metals that exhibit high-performance brazing characteristics both for different metals/alloys and for ceramics [1-5]. The bibliography on Ag-Cu-Ti braze alloys is quite extensive but there are still many unanswered questions related to the phase transformations that occur during brazing processes. In our own previous studies involving Ti-modified $\mathrm{Ag}-\mathrm{Cu}$ near-eutectic braze alloys there were several issues which remained unexplained, like porosity in the joints or the process parameters (time, temperature, vacuum). Having not found any comprehensive thermodynamic or phase analysis of the Ag-Cu-Ti system applicable to brazing processes, we decided to look closer at the phase transformations that occur in the $\mathrm{Ag} 70.5 \mathrm{Cu} 26.5 \mathrm{Ti} 3$ alloy (known also as CB4) and address several issues related to brazing processes, like segregation of liquid, the role of titanium, wetability, etc. This analysis, which is based on published phase diagrams and some related experimental and theoretical studies, we hope, clarifies some issues related to the brazing technology and could be useful for other Ag-Cu-Ti alloys or similar systems.

\section{Experimental}

Though in this study we do not emphasize on our experimental findings, we still have to give some details of our practical work in order to correctly apply the theory to the experiment. In our studies on joining $\mathrm{Y}_{2} \mathrm{O}_{3}$-to- $\mathrm{Y}_{2} \mathrm{O}_{3}, \mathrm{Y}_{2} \mathrm{O}_{3}$-to-Zr, $\mathrm{Zr}$-to-Zr, $\mathrm{Si}_{3} \mathrm{~N}_{4}$-to-(410 type stainless steel) we used the commercially available active filler metal $\mathrm{Ag} 70.5 \mathrm{Cu} 26.5 \mathrm{Ti} 3$ (wt.\%), known as CB4 [6-9]. Usually, our samples for brazing were made as round sandwiches with a piece of $0.13 \mathrm{~mm}$ thick braze alloy foil inserted between the pieces of the brazed materials. These sandwiches were placed in a quartz tube of a vacuum furnace where the pressure was kept within $10^{-1} \ldots 10^{-4} \mathrm{~Pa}$ during the heating-cooling campaign. The maximum temperature for the brazing process was $900{ }^{\circ} \mathrm{C}$, which is right in the middle of the recommended brazing temperature range $850-950{ }^{\circ} \mathrm{C}$ for this filler metal [4]. The equilibration time in the different experiments ranged from 6 to $60 \mathrm{~min}$.

The initial microstructure of the braze alloy CB4 (Fig. 1) consists of an Ag-rich matrix, Cu-rich inclusions (both structures are FCC), and coppertitanium intermetallics, usually associated only with a $\mathrm{Cu}$-rich phase, as was reported in the previous works [6-9]. Compositionally, when converted to atomic 


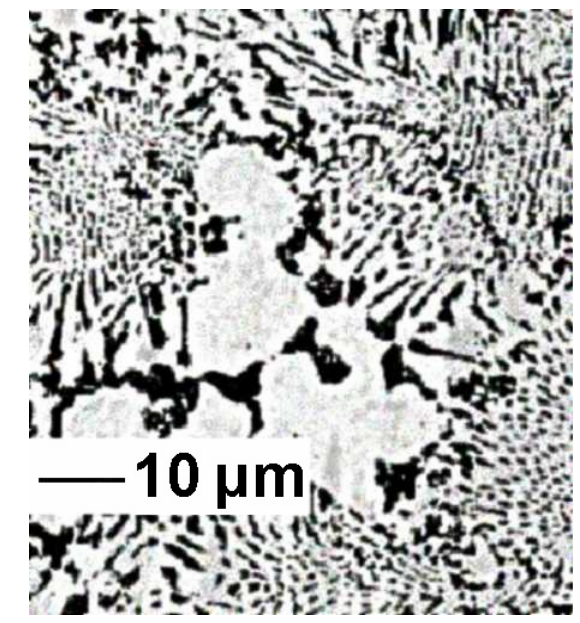

Fig. 1 SEM image of an as-received brazing alloy $\mathrm{Ag} 70.5 \mathrm{Cu} 26.5 \mathrm{Ti} 3(\mathrm{CB} 4)$.

concentrations, this alloy has the stoichiometry $\mathrm{Ag}_{57.5} \mathrm{Cu}_{37} \mathrm{Ti}_{5.5}$, which could be considered as an $\mathrm{Ag}_{60} \mathrm{Cu}_{40}$ eutectic modified with 5.5 at.\% of titanium. With this initial information let's turn to searching and analyzing the available phase diagrams and related structural, thermodynamic and other data.

\section{Selection of the phase diagrams}

For the analysis of melting/solidification of CB4, the phase diagrams for $\mathrm{Ag}-\mathrm{Cu}-\mathrm{Ti}$ and for the relevant binary systems have to be located and related information has to be found. The $\mathrm{Ag}-\mathrm{Cu}$ binary system, having a positive heat of mixing in both the solid and liquid states, is categorized in a group of segregating systems. Being practically immiscible in the solid state at room temperature [10], silver and copper form a single liquid phase due to the large entropic contribution to the free energy of mixing at high temperatures. However, the statistical mechanical modeling of $\mathrm{Ag}-\mathrm{Cu}$ melts suggests that even in this seemingly homogeneous liquid there is a tendency for homo-coordination, i.e. to a weak demixing, a tendency inversely proportional to the temperature and thus manifested mostly at near-eutectic temperatures [11].

The introduction of titanium into the $\mathrm{Ag}-\mathrm{Cu}$ eutectic mix changes the energetics of the system. Contrary to the segregating interactions between $\mathrm{Ag}$ and $\mathrm{Cu}$, both the $\mathrm{Ag}$ - $\mathrm{Ti}$ and the $\mathrm{Cu}-\mathrm{Ti}$ systems exhibit high negative values for the heat of mixing leading to spontaneous heteroatomic coordination, which is reflected in the formation of intermetallic compounds, and thus these systems are classified as compoundforming [12-15].

Titanium has higher affinity to copper than to silver; the $\mathrm{Cu}-\mathrm{Ti}$ bonds are stronger, i.e. have more negative values of the Gibbs energy of mixing and, consequently, are more preferred than the Ag-Ti ones.
This is reflected in the binary phase diagrams, which exhibit only two intermetallic compounds for the Ag$\mathrm{Ti}$ system and six intermetallics for the $\mathrm{Cu}-\mathrm{Ti}$ system - two phases and four line compounds [10].

In the binary Ag-Ti system there are two intermetallics, $\mathrm{AgTi}$ and $\mathrm{AgTi}_{2}$, however, there is discussion on the existence of $\mathrm{AgTi}_{3}$ and some disagreement on the shape of the Ag-Ti phase diagram can be found [10,16-23].

The binary $\mathrm{Cu}-\mathrm{Ti}$ system appears much more complicated with a long list of published stoichiometries for $\mathrm{Cu}-\mathrm{Ti}$ intermetallics - $\mathrm{CuTi}_{3}$, $\mathrm{CuTi}_{2}, \mathrm{CuTi}, \mathrm{Cu}_{4} \mathrm{Ti}_{3}, \mathrm{Cu}_{3} \mathrm{Ti}_{2}, \mathrm{Cu}_{2} \mathrm{Ti}, \mathrm{Cu}_{3} \mathrm{Ti}, \mathrm{Cu}_{7} \mathrm{Ti}_{2}$ or $\mathrm{Cu}_{3} \mathrm{Ti} \cdot \mathrm{Cu}_{4} \mathrm{Ti}, \mathrm{Cu}_{4} \mathrm{Ti}$ - some exhibiting allotropy. A few of them were reported once or twice many years ago and have not been confirmed by experimental studies ever since, like $\delta-\mathrm{CuTi}, \mathrm{Cu}_{3} \mathrm{Ti}$ (any form: $\alpha-, \beta$-, or $\beta^{\prime}-$ ) or $\mathrm{Cu}_{7} \mathrm{Ti}_{2}$. Others, like $\mathrm{CuTi}_{3}$ and $\alpha-\mathrm{Cu}_{4} \mathrm{Ti}(\mathrm{LT})$, were revitalized in a recent review by Okamoto [24]. The former, a suggested tetragonal $\mathrm{CuTi}_{3}(P 4 / \mathrm{mmm})$, that appeared in the early 1950-s, was claimed again in 2002 based on DTA studies [24-27]. The latter, initially an unsolved lowtemperature modification of $\mathrm{Cu}_{4} \mathrm{Ti}$, published in 1983 and ignored by numerous studies since then, is probably related to $\alpha-\mathrm{Cu}_{4} \mathrm{Ti}$ of $\mathrm{Ni}_{4} \mathrm{Mo}$-type structure (tI10) mentioned by Okamoto [24,28]. Besides, there are misprints, mistakes and erroneous speculations in the reported thermodynamic and crystallographic data, which could easily be traced [19,24,29].

The relatively low credibility of some physicochemical parameters stem from the high reactivity of titanium with practically all crucible-making materials and with oxygen and nitrogen in the surrounding, which causes the chemistry and thus the energetics of the studied system to be modified, often significantly. In the case of the silver-containing system (Ag-Ti) the volatility of silver introduces an additional problem [23]. These factors make the experimental studies rather hard and the old experimental works very valuable.

Searching for the most recent publications related to the $\mathrm{Cu}$-Ti phase diagrams, one can assume that the phase relations in this system do not differ much from those published in the early work by Eremenko et al. $[16,29,30]$. Eremenko's $\mathrm{Cu}-\mathrm{Ti}$ diagram exhibits six intermetallics - $\mathrm{CuTi}_{2}, \mathrm{CuTi}, \mathrm{Cu}_{4} \mathrm{Ti}_{3}, \mathrm{Cu}_{3} \mathrm{Ti}_{2}, \mathrm{Cu}_{2} \mathrm{Ti}$, and $\mathrm{Cu}_{4} \mathrm{Ti}$. The list was confirmed by a) the popular handbook by Massalski [10], who incorporated the work of Murray [20,21] and the studies of b) Paulasto et al. [23], c) Kumar et al. [12], d) Arroyave [31,32], and e) Shiue et al. [33]. The shape of the diagrams published by Eremenko et al. [29,30] remained almost unchanged except for the $\mathrm{L} \leftrightarrow \mathrm{CuTi}_{2}$ transformation, which was corrected from congruent (Eremenko et al. called it distectic) to peritectic (Fig. 2). Also, the compositional boundaries for the intermediate phases $\mathrm{CuTi}$ and $\mathrm{Cu}_{4} \mathrm{Ti}$ and the temperatures for invariant points appeared adjusted first in the handbook by Massalski [10] and lately in several studies based on 

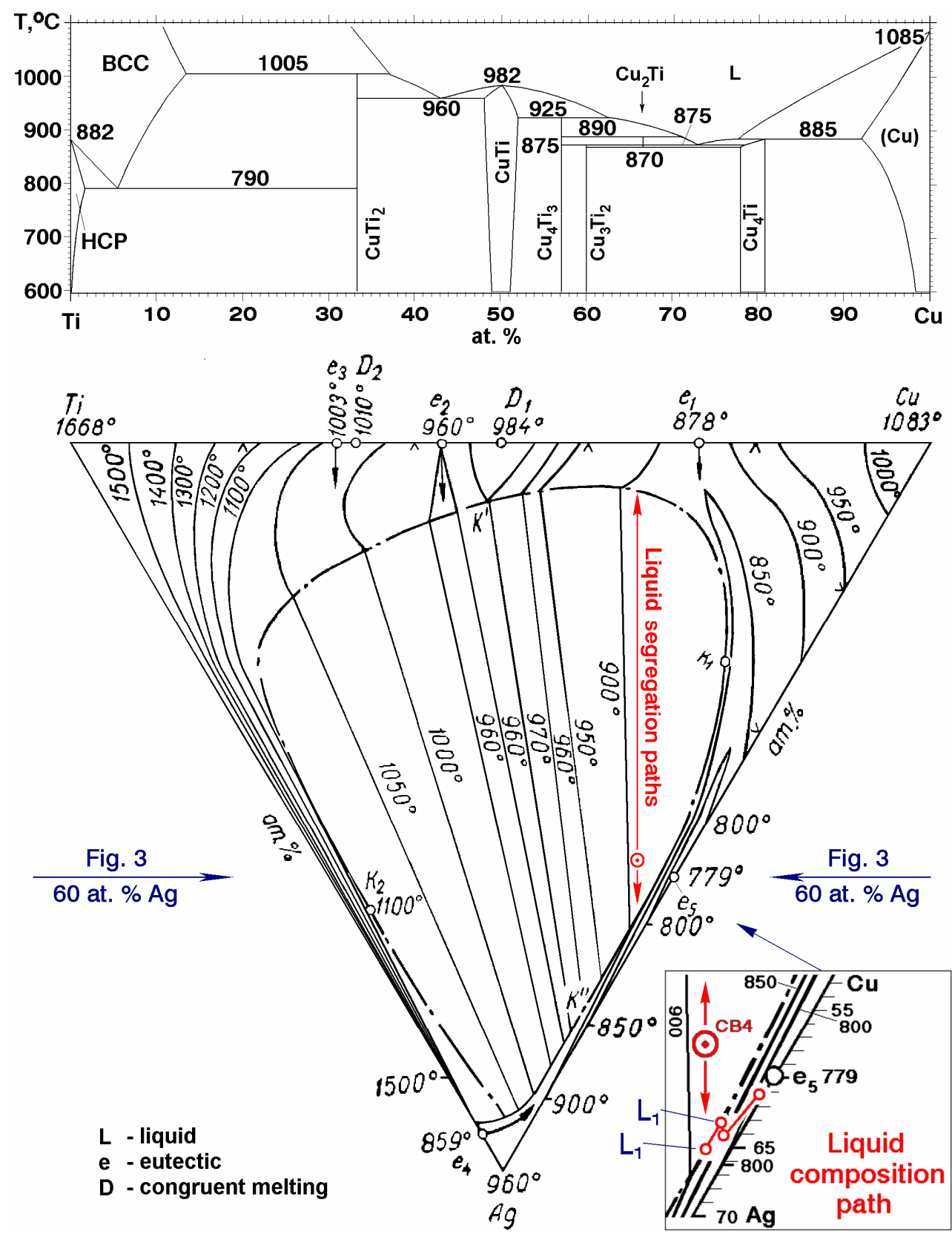

Fig. 2 Liquidus surface projection onto the Ti-Cu-Ag compositional triangle (bottom) [16] and Ti-Cu phase diagram (top) transformed from [10]. Designations: $-\boldsymbol{\bullet}-$ - boundary of the miscibility gap; $\leftarrow \odot \rightarrow-$ composition of CB4 and liquid segregation paths.

computer (Calphad) modeling [12,24,31,32]. We transformed the experimentally-based $\mathrm{Cu}$-Ti diagram published by Massalski in order to couple it with the ternary Ag-Cu-Ti diagram (Fig. 2) for better understanding of the phase transformations in the Ag-Cu-Ti system.

The search for ternary Ag-Cu-Ti phase diagrams resulted in finding just a few independent studies. The earliest (1969-1970) most comprehensive experimental investigation was conducted by Eremenko et al. [16,30,34,35]. In 1977 Chang et al. [19] revised the available data for the ternary
$\mathrm{Ag}-\mathrm{Cu}-\mathrm{Ti}$ system and redrew three diagrams from Eremenko et al., missing, however, their major summarizing publication [30] with seven sections of the Ag-Cu-Ti system. The collection of Petzow and Effenberg issued in 1988 reproduced the same three diagrams [36] and only in 1996 the rest of the missed diagrams of Eremenko et al. were included in the handbook compiled by Villars et al. [37]. A new set of experimental data and two isothermal sections calculated for the Ag-Cu-Ti system were published by Paulasto et al. in 1995 [23]. Finally, a thermodynamic model for this ternary system was performed by 
Arroyave and Eagar and a calculated $700^{\circ} \mathrm{C}$ isothermal section was published in 2004 [38]. These last two sources do not principally change the first published diagrams and it seems justified to use the original diagrams by Eremenko et al. For better perception we combined (Fig. 2) the liquidus surface projection of the ternary Ag-Cu-Ti diagram with the binary $\mathrm{Ti}-\mathrm{Cu}$ diagram converted from the one published in Massalski's handbook [10,16].

The diagram (Fig. 2) exhibits a wide miscibility gap in the ternary liquid phase where the liquid segregates into two liquids:

$$
\mathrm{L}=\mathrm{L}_{1}+\mathrm{L}_{2} \text {, }
$$

$\mathrm{L}_{1}$ tending towards the $\mathrm{Ag}-\mathrm{Cu}$ edge with low $\mathrm{Ti}$ content and $\mathrm{L}_{2}$ tending towards the $\mathrm{Cu}-\mathrm{Ti}$ edge with relatively low $\mathrm{Ag}$ content, though it is sometimes thought that the segregating $\mathrm{Ag}-\mathrm{Cu}$ system have to split into the Ag-Ti and $\mathrm{Cu}$-Ti liquids. Separation into $\mathrm{Cu}-\mathrm{Ti}$ and $\mathrm{Ag}-\mathrm{Cu}$, however, points to the role of copper. Indeed, $\mathrm{Cu}$ with its small atomic size must have a crucial role in defining the energetics of the interatomic interactions and, specifically, the entropic terms of the Gibbs free energies, thus defining the coordinating preferences within the $\mathrm{Ag}-\mathrm{Cu}-\mathrm{Ti}$ liquid.

The composition of the braze alloy CB4, $\mathrm{Ag}_{57.5} \mathrm{Cu}_{37} \mathrm{Ti}_{5.5}$, shown as $\odot$ (Fig. 2), falls inside the miscibility loop, somewhat lower than the $900{ }^{\circ} \mathrm{C}$ isotherm on the liquidus projection, confirming that $900{ }^{\circ} \mathrm{C}$ is sufficient for complete melting of the filler metal. We constructed the isotherm that crosses the point corresponding to the composition of CB4 and designated it with two arrows showing the segregation paths. Upon reaching the miscibility boundary line, these arrows point to the compositions of $\mathrm{L}_{1}$ and $\mathrm{L}_{2}$ formed by the segregating action.

Estimated from the miscibility gap, the studied braze alloy segregates into $\mathrm{L}_{1}=\mathrm{Ag}_{65.0} \mathrm{Cu}_{33.2} \mathrm{Ti}_{1.8}$ (87 at.\%) and $\mathrm{L}_{2}=\mathrm{Ag}_{6.7} \mathrm{Cu}_{62.6} \mathrm{Ti}_{30.7}$ (13 at.\%). The chemistry of $\mathrm{L}_{1}$ is close to the $\mathrm{Ag}-\mathrm{Cu}$ eutectic, while $\mathrm{L}_{2}$ exhibits apparent $\mathrm{Cu}_{2} \mathrm{Ti}$ stoichiometry, which is close to the lowest $\mathrm{Cu}$-Ti eutectic $\left(\sim 870{ }^{\circ} \mathrm{C}\right)$. Note that the intermetallic phase $\mathrm{Cu}_{2} \mathrm{Ti}$ exists only in a narrow temperature range between $850-860$ and $880-890{ }^{\circ} \mathrm{C}$, i.e. just below the liquidus surface.

Now the questions arise: a) how does the temperature affect the stabilities of the phases and their compositions before the braze alloy is completely melted and segregated into $\mathrm{L}_{1}$ and $\mathrm{L}_{2}$ and b) how do the phase transformations that occur between the solidus and liquidus points influence wetting/spreading during the brazing process? This and other useful information could be derived from one of Eremenko's vertical sections of the ternary $\mathrm{Ag}-\mathrm{Cu}-\mathrm{Ti}$ system [30]. Since the composition of CB4 is close to the $\mathrm{Ag}_{60} \mathrm{Cu}_{40}$ eutectic and because the $\mathrm{Ti}-\mathrm{Cu}$ interactions dominate in this system, a vertical $\mathrm{Cu}-\mathrm{Ti}$ section of the Ag-Cu-Ti system for fixed $60 \%$ $\mathrm{Ag}$ could be very useful for an analysis of CB4, especially because this section is almost normal to the isotherms on the liquidus surface. In Fig. 2 this section is designated with two arrows near the Ag-Ti and Ag$\mathrm{Cu}$ lines. Fig. 3 depicts this $\mathrm{Ti}-\mathrm{Cu}-(60 \% \mathrm{Ag})$ section within the $700-1100{ }^{\circ} \mathrm{C}$ temperature frame.

The CB4 segregation paths (two vertical arrows in Fig. 2) appear exactly normal to the $\mathrm{Ti}-\mathrm{Cu}-(60 \% \mathrm{Ag})$ section so we can make a normal projection and obtain a) the position of the liquidus point (marked as $\odot$ in Fig. 3) and b) the heating-cooling path for the alloy under equilibrium conditions. This path crosses the $\mathrm{Cu}-\mathrm{Ti}$ composition axis at $4.25 \% \mathrm{Ti}-35.75 \% \mathrm{Cu}$ (marked as $\odot$ below the axis in Fig. 3 ). Using the composition of the liquid phase calculated from Fig. 2, we can perform a phase analysis and study the redistribution of the elements among all the phases.

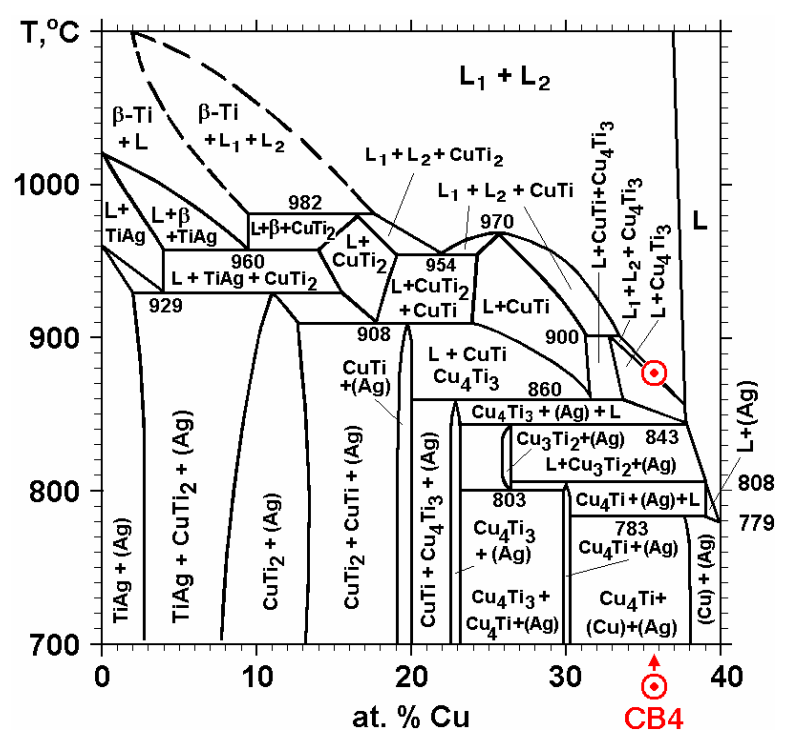

Fig. 3 Vertical Cu-Ti-(60\% Ag) section of the $\mathrm{Ag}-\mathrm{Cu}-\mathrm{Ti}$ system [30]. $\odot-$ composition of CB4.

\section{Cooling path of the melted CB4}

The liquidus temperature of $\mathrm{CB} 4$, according to Fig. 3, is $877^{\circ} \mathrm{C}$. The liquid is segregated to $87 \% \mathrm{~L}_{1}+13 \% \mathrm{~L}_{2}$, the compositions being $\mathrm{Ag}_{65.0} \mathrm{Cu}_{33.2} \mathrm{Ti}_{1.8}$ and $\mathrm{Ag}_{6.7} \mathrm{Cu}_{62.6} \mathrm{Ti}_{30.7}$, respectively. With a decrease of temperature the cooling path enters the $\left(\mathrm{L}_{1}+\mathrm{L}_{2}+\mathrm{Cu}_{4} \mathrm{Ti}_{3}\right)$ domain, which is characterized by precipitation of the first intermetallic compound $\mathrm{Cu}_{4} \mathrm{Ti}_{3}$ from $\mathrm{L}_{2}$ (note that $\mathrm{L}_{2}$ corresponds to $\mathrm{Cu}_{2} \mathrm{Ti}$ stoichiometry). With the precipitation of $\mathrm{Cu}_{4} \mathrm{Ti}_{3}$ several processes can be observed and quantitatively estimated:

a) the amount of $\mathrm{L}_{2}$ quickly decreases from $13 \%$ to $0 \%$,

b) all $\mathrm{Ag}\left(\mathrm{L}_{2}\right)$ and the excess $\mathrm{Cu}\left(\mathrm{L}_{2}\right)$ diffuse from $\mathrm{L}_{2}$ to $\mathrm{L}_{1}$,

c) the composition of $\mathrm{L}_{1}$ is modified (Fig. 2) along the miscibility loop, changing from $\mathrm{Ag}_{65.0} \mathrm{Cu}_{33.2} \mathrm{Ti}_{1.8}$ to $\mathrm{Ag}_{63.2} \mathrm{Cu}_{35.0} \mathrm{Ti}_{1.8}$, and

d) the amount of $\mathrm{L}_{1}$ increases from 87 to 91 at.\% and is balanced with $9 \%$ of solid $\mathrm{Cu}_{4} \mathrm{Ti}_{3}$ phase. With the 
consumption of $\mathrm{L}_{2}$, the remaining homogeneous liquid $\mathrm{L}_{1}$ is from now on designated $\mathrm{L}$.

When the temperature drops below $874{ }^{\circ} \mathrm{C}$ (Fig. 3) the cooling path enters the $\left(\mathrm{L}+\mathrm{Cu}_{4} \mathrm{Ti}_{3}\right)$ domain. The direction of the liquid composition path changes abruptly towards enrichment in Ag and depletion in $\mathrm{Ti}$ (Fig. 2). The liquid is now balanced only with one phase, $\mathrm{Cu}_{4} \mathrm{Ti}_{3}$, of which one additional percent precipitates, causing the composition of the liquid phase to change from $\mathrm{Ag}_{63.2} \mathrm{Cu}_{35.0} \mathrm{Ti}_{1.8}$ to $\mathrm{Ag}_{63.9} \mathrm{Cu}_{34.7} \mathrm{Ti}_{1.4}$.

Moving below $852{ }^{\circ} \mathrm{C}$ the cooling path enters the $\left(\mathrm{L}+\mathrm{Cu}_{4} \mathrm{Ti}_{3}+\mathrm{Ag}[\mathrm{Cu}]\right)$ domain. Here a second solid phase precipitates: FCC $\mathrm{Ag}[\mathrm{Cu}]$. The solubility of copper in $\mathrm{Ag}$ at these temperatures is about 8.5 at.\%, while the solubility of titanium in this $\mathrm{Ag}-8.5 \mathrm{Cu}$ solid solution is rather low and we ignore it in our approximate calculations. Once again we see an abrupt change in the liquid composition path (Fig. 2) because the precipitation of $\mathrm{Ag}[\mathrm{Cu}]$ phase causes the composition of the liquid to shift in the direction of the $\mathrm{Ag}-\mathrm{Cu}$ eutectic. This, in turn, stimulates the precipitation of $\mathrm{Cu}_{4} \mathrm{Ti}_{3}$. According to our estimates, the amount of the precipitated phases, i.e. $\mathrm{Ag}[\mathrm{Cu}]$ and $\mathrm{Cu}_{4} \mathrm{Ti}_{3}$, is of the order of $2 \%$ with the ratio $3: 2$ and the final phase composition at $843{ }^{\circ} \mathrm{C}$ is: $88 \%$ $\mathrm{L}=\mathrm{Ag}_{64.1} \mathrm{Cu}_{34.9} \mathrm{Ti}_{1.0}, \quad 11 \% \mathrm{Cu}_{4} \mathrm{Ti}_{3}$ and $1 \% \mathrm{Ag}[\mathrm{Cu}]$. The noticeable discrepancy between our calculations $(\sim 1 \%)$ and Fig. $3(\sim 2 \%)$ for the solubility of titanium in the liquid phase in the $60 \mathrm{Ag}-\mathrm{Cu}$ alloy at this temperature is probably connected to the precision of the almost 40-year old hand drawings.

At $843{ }^{\circ} \mathrm{C}$, according to Eremenko et al. [30], the following reaction takes place:

$$
\mathrm{L}+\mathrm{Cu}_{4} \mathrm{Ti}_{3}=\mathrm{Cu}_{3} \mathrm{Ti}_{2}+\mathrm{Ag}[\mathrm{Cu}]
$$

and the cooling path enters the $\left(\mathrm{L}+\mathrm{Cu}_{3} \mathrm{Ti}_{2}+\mathrm{Ag}[\mathrm{Cu}]\right)$ domain. This reaction at $843{ }^{\circ} \mathrm{C}$ a) consumes about $3 \%$ of the liquid phase; b) turns all $\mathrm{Cu}_{4} \mathrm{Ti}_{3}$ into $\mathrm{Cu}_{3} \mathrm{Ti}_{2}$; c) precipitates about $2 \%$ of $\mathrm{Ag}-8.5 \mathrm{Cu}$ phase. Further cooling causes the composition of the liquid to shift towards the $\mathrm{Ag}-\mathrm{Cu}$ eutectic and thus more $\mathrm{Ag}[\mathrm{Cu}]$ phase has to precipitate. The solubility of $\mathrm{Cu}$ in FCC $\mathrm{Ag}$ at the bottom of this domain $\left(808^{\circ} \mathrm{C}\right)$ increases to ca. 11.5 at.\%. At the same time, the solubility of $\mathrm{Ti}$ in the liquid gradually decreases. The estimated phase composition just above the $808{ }^{\circ} \mathrm{C}$ boundary line is the following: $78 \% \mathrm{~L}=\mathrm{Ag}_{63.2} \mathrm{Cu}_{36.2} \mathrm{Ti}_{0.6}, 13 \% \mathrm{Cu}_{3} \mathrm{Ti}_{2}$ and $9 \% \mathrm{Ag}-11.5 \mathrm{Cu}$.

Similarly, at $808^{\circ} \mathrm{C}$, when the cooling path enters the $\left(\mathrm{L}+\mathrm{Cu}_{4} \mathrm{Ti}+\mathrm{Ag}[\mathrm{Cu}]\right)$ domain, the formation of $\mathrm{Cu}_{4} \mathrm{Ti}$ from $\mathrm{Cu}_{3} \mathrm{Ti}_{2}$ occurs according to:

$$
\mathrm{L}+\mathrm{Cu}_{3} \mathrm{Ti}_{2}=\mathrm{Cu}_{4} \mathrm{Ti}+\mathrm{Ag}[\mathrm{Cu}] \text {. }
$$

This reaction turns all $\mathrm{Ti}$ contained in $\mathrm{Cu}_{3} \mathrm{Ti}_{2}$ into $\mathrm{Cu}_{4} \mathrm{Ti}$ (in our calculation we take this intermediate phase as a stoichiometric compound) and consumes about $2 / 3$ of the remaining liquid, while precipitating $35 \% \mathrm{Ag}[\mathrm{Cu}]$ phase. This is the most important reaction with respect to the amount of matter involved and the amount of liquid transformed to solid. When this reaction is completed, just below $808^{\circ} \mathrm{C}$, the phase composition is estimated as follows: $29 \% \mathrm{~L}=\mathrm{Ag}_{63.2} \mathrm{Cu}_{36.2} \mathrm{Ti}_{0.6}, \quad 27 \% \mathrm{Cu}_{4} \mathrm{Ti}$ and $44 \%$ $\mathrm{Ag}-11.5 \mathrm{Cu}$. Further cooling down to $783{ }^{\circ} \mathrm{C}$ is possible only if the composition of the liquid shifts closer to the 60:40 stoichiometry and thus additional $\mathrm{Ag}[\mathrm{Cu}]$ has to precipitate. The solubility of $\mathrm{Cu}$ in $\mathrm{Ag}$ further increases from 11.5 to 13.8 at.\%. At the same time the solubility of $\mathrm{Ti}$ in the liquid decreases. The estimated phase composition just above the $783{ }^{\circ} \mathrm{C}$ boundary line is the following: $53 \% \mathrm{Ag}[\mathrm{Cu}$, $27 \% \mathrm{Cu}_{4} \mathrm{Ti}$ and $20 \% \mathrm{~L}=\mathrm{Ag}_{60.7} \mathrm{Cu}_{39.1} \mathrm{Ti}_{0.2}$.

At $783{ }^{\circ} \mathrm{C}$ the last portion of liquid phase solidifies according to:

$$
\mathrm{L}+\mathrm{Cu}_{4} \mathrm{Ti}=\mathrm{Cu}[\mathrm{Ag}, \mathrm{Ti}]+\mathrm{Ag}[\mathrm{Cu}]
$$

where $\mathrm{Cu}[\mathrm{Ag}, \mathrm{Ti}]$ is the solid solution in FCC copper. According to the binary $\mathrm{Cu}-\mathrm{Ti}$ diagram (Fig. 2), at this temperature $\mathrm{Cu}$ dissolves $4 \% \mathrm{Ti}$. In the ternary $\mathrm{Ag}$ $\mathrm{Cu}-\mathrm{Ti}$ system this phase accommodates comparable amounts of $\mathrm{Ag}$ and $\mathrm{Ti}$, at least according to the published ternary sections for 700 and $900{ }^{\circ} \mathrm{C}[30,37]$. The most recent calculations of the $700{ }^{\circ} \mathrm{C}$ ternary section of the Ag-Cu-Ti diagram suggest solubilities of $\mathrm{Ag}$ and $\mathrm{Ti}$ in $\mathrm{Cu}$ of about 3-3.5\% for each element $[31,38]$. At $783{ }^{\circ} \mathrm{C}$ the solubilities have to be higher and it seems reasonable to take the composition of this phase to be $\mathrm{Cu}-4 \mathrm{Ag}-4 \mathrm{Ti}$. When all these phases are balanced the following numbers are obtained: a) $1.3 \%$ of the existent $\mathrm{Cu}_{4} \mathrm{Ti}$ is consumed for the reaction; b) $7.5 \% \mathrm{Cu}[\mathrm{Ag}, \mathrm{Ti}]$ and additional $13.5 \% \mathrm{Ag}[\mathrm{Cu}]$ are produced; c) below the $783^{\circ} \mathrm{C}$ boundary line the phase composition of $\mathrm{CB} 4$ is the following:

$26 \% \mathrm{Cu}_{4} \mathrm{Ti}+66.5 \% \mathrm{Ag}[\mathrm{Cu}]+7.5 \% \mathrm{Cu}[\mathrm{Ag}, \mathrm{Ti}]$.

Further cooling to room temperature would result in the precipitation of some $\mathrm{Cu}_{4} \mathrm{Ti}$ and depletion of solid solutions, i.e. $\mathrm{Ag}[\mathrm{Cu}]$ and $\mathrm{Cu}[\mathrm{Ag}, \mathrm{Ti}]$, from solutes so that the final equilibrium composition of CB4 is

$27.5 \% \mathrm{Cu}_{4} \mathrm{Ti}+57.5 \% \mathrm{Ag}[\mathrm{Cu}]+15 \% \mathrm{Cu}[\mathrm{Ag}, \mathrm{Ti}]$.

However, if we compare the published values for the solidus and liquidus points of commercially available CB4, namely 803 and $857^{\circ} \mathrm{C}$ [2], we notice apparent deviation from the values derived in the above phase analysis, i.e. 783 and $877^{\circ} \mathrm{C}$. The possible sources for this discrepancy are: a) inaccuracy of the source diagrams; b) Fig. 3 was constructed for $60 \% \mathrm{Ag}$, not for $57.5 \%$; c) the asreceived alloy is not at equilibrium; and $d$ ) the published values for the solidus-liquidus melting range are also non-equilibrium.

Looking at the CB4 heating path (Fig. 3) and at the temperature dependence of the amount of liquid phase (Fig. 4) it could be suggested that the solidus point published for $\mathrm{CB} 4,803{ }^{\circ} \mathrm{C}$, corresponds to the $\mathrm{Cu}_{4} \mathrm{Ti} \leftrightarrow \mathrm{Cu}_{3} \mathrm{Ti}_{2}$ transformation at $808{ }^{\circ} \mathrm{C}$, described above. If one deals with a non-equilibrium alloy and non-equilibrium thermal methods for studying phase transformations it is possible that the solidus stage at $783{ }^{\circ} \mathrm{C}$, involving the $\mathrm{Cu}[\mathrm{Ag}, \mathrm{Ti}] \leftrightarrow \mathrm{Cu}_{4} \mathrm{Ti}$, transformation is not detected. The $\mathrm{Cu}_{4} \mathrm{Ti} \leftrightarrow \mathrm{Cu}_{3} \mathrm{Ti}_{2}$ transformation at $808^{\circ} \mathrm{C}$ could not be ignored, 


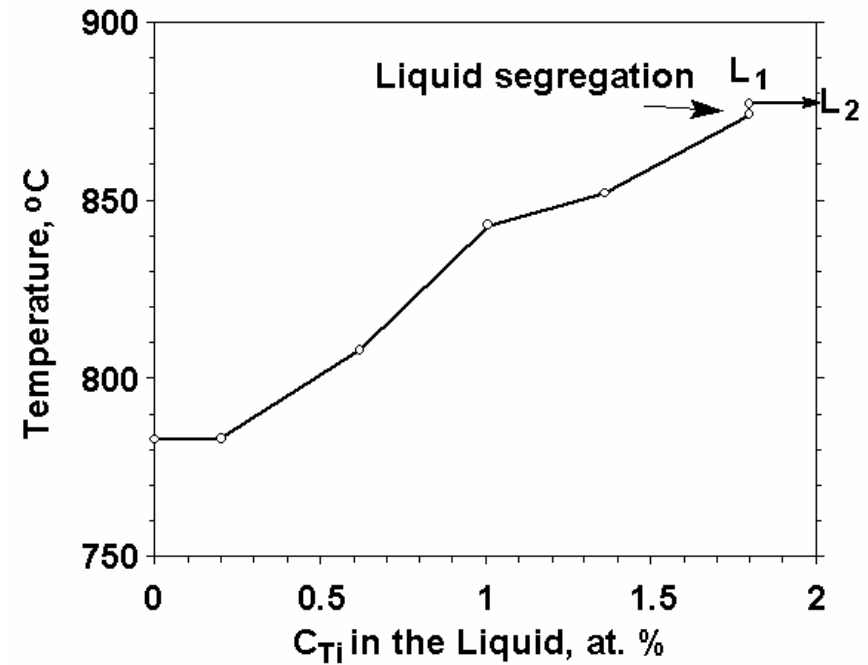

a)

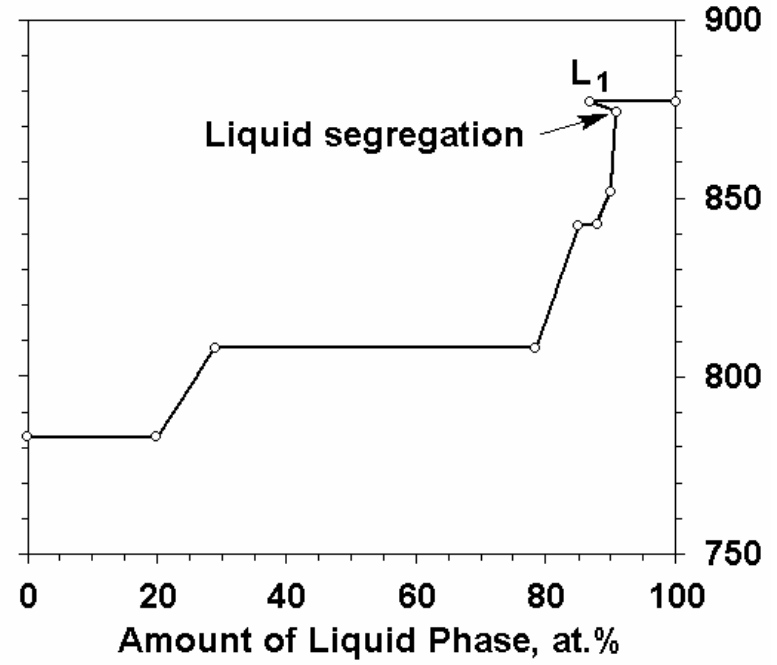

b)

Fig. 4 Temperature dependence of a) the concentration of Ti in the liquid phase and b) the amount of liquid phase.

however, since it is the most prominent transformation in the alloy.

As to the liquidus point published for CB4 $\left(857^{\circ} \mathrm{C}\right)$, it falls into the $\left(\mathrm{L}+\mathrm{Cu}_{4} \mathrm{Ti}_{3}\right)$ domain. It is hard to blame non-equilibrium conditions for this discrepancy since the temperature is high and the amount of liquid is about $90 \%$. Responsible for this error could be the high reactivity of $\mathrm{Ti}$, poor experimental set-up or a mistake in the diagram (Fig. 3), which, as pointed out above, is not the correct section, but is slightly shifted towards higher $\mathrm{Ag}$ values.

The above results conclude the analysis of the cooling path of melted CB4, which could also be read in the opposite direction, i.e. as a heating path. Now, knowing the effect of temperature on the phase transformations and compositions, we can look at how this information may be applied in an analysis of the processes that occur during brazing.

\section{Discussion}

\section{Melting at the solidus point}

There are several observations related to the melting of the braze alloy CB4. Firstly, at low temperatures the third equilibrium phase besides the Ag- and $\mathrm{Cu}$-based solid solutions is $\mathrm{Cu}_{4} \mathrm{Ti}$. The presence of $\mathrm{Cu}_{3} \mathrm{Ti}_{2}$ phase in the analysis of the as-received CB4 alloy reported earlier [7] proves that this alloy was not at equilibrium. Possibly, when the alloy is heated, $\mathrm{Cu}_{3} \mathrm{Ti}_{2} \rightarrow \mathrm{Cu}_{4} \mathrm{Ti} \rightarrow \mathrm{Cu}_{3} \mathrm{Ti}_{2}$ transformations take place at about $808{ }^{\circ} \mathrm{C}$ and no detectable $\mathrm{Cu}_{4} \mathrm{Ti} \rightarrow \mathrm{Cu} \rightarrow \mathrm{Cu}_{4} \mathrm{Ti}$ transformations are observed around $783{ }^{\circ} \mathrm{C}$. This could explain the reported solidus point for this alloy.

Secondly, the solidus point is located higher than the $\mathrm{AgCu}$ eutectic $\left(779^{\circ} \mathrm{C}\right)$. This is because titanium is present in the FCC copper solid solution. We assume that at this temperature copper dissolves about $4 \% \mathrm{Ti}$ and $4 \% \mathrm{Ag}$. There is also some solubility of titanium in $\mathrm{FCC} \mathrm{Ag}[\mathrm{Cu}]$, though the published experimental works do not give us any significant number. The dissolved titanium causes the $\mathrm{AgCu}$ eutectic point to rise.

Thirdly, even under equilibrium conditions the very first portion of liquid should contain some titanium, though a small amount. Estimated from Fig. 3 and verified with Fig. 2 this concentration should be $0.15-0.2 \%$. For a non-equilibrium alloy this number has to be higher.

Fourthly, at $808^{\circ} \mathrm{C}$ the major part of the alloy (whether at equilibrium or not) is melted. Only about $20 \%$ of the alloy remains solid (Fig. 4). At this point the issue of wetability becomes important.

\section{Ti activity in the liquid}

At $808{ }^{\circ} \mathrm{C}$ there is a significant amount of titanium dissolved in the liquid. Estimations based on Fig. 2 gave $0.6 \%$, while from Fig. 3 we derived about $1 \%$ Ti. Based on the above calculations we plotted the temperature dependence of the amount of liquid phase and the Ti concentration in the liquid (Fig. 4) in order to better visualize the role of titanium in the brazing process. It is clear that further increase of the temperature stimulates an increase of the $\mathrm{Ti}$ concentration in the liquid. The concentration of $\mathrm{Ti}$ in the liquid becomes $1.4 \%$ before the last portion of solid $\left(\mathrm{Cu}_{4} \mathrm{Ti}_{3}\right)$ is finally melted and the liquid is segregated into two immiscible liquids. According to Fig. 3 this number exceeds $2 \%$. Now a question appears: Is 1-2\% Ti enough for reactive-wetting action of the liquid? Since titanium in the liquid has to work as a reactive element, the activity of $\mathrm{Ti}\left(a_{\mathrm{Ti}}\right)$ is a more important parameter than its concentration $\left(X_{T i}\right)$. 
Fortunately, there exists a study on the Ti activity coefficients $\left(\gamma_{\mathrm{Ti}}=a_{\mathrm{Ti}} / X_{\mathrm{Ti}}\right)$ in Ag-Cu liquids based on the experimental work by Pak et al. [13]. It was established that the titanium activity in $\mathrm{Ag}-\mathrm{Cu}$ liquids exhibits a positive deviation from ideal solution behavior. Though the measurements were performed at $1000{ }^{\circ} \mathrm{C}$, the positive deviation should stand true for the lower temperatures of the $\mathrm{CB} 4$ melting range. It was calculated that for the $\mathrm{Ag}_{59.1} \mathrm{Cu}_{39} \mathrm{Ti}_{1.9}$ liquid at $1000{ }^{\circ} \mathrm{C} \gamma_{\mathrm{Ti}}=4.5$. For the Ag-Cu eutectic the activity of titanium at infinite dilution was extrapolated to be $\gamma_{T i}=6.5$ (these numbers are relative to pure solid titanium at $1000{ }^{\circ} \mathrm{C}$ ). This means that even the very first liquid, which appears above the solidus point of the studied alloy, though it contains only about $0.2 \% \mathrm{Ti}$, still has to be reactive. With increasing temperature, when the $\mathrm{Ti}$ content in the liquid increases the liquid should become more and more reactive.

The work of Pak et al. has demonstrated a very important relationship: the increased $\mathrm{Ti}$ activity in the $\mathrm{Ag}-\mathrm{Cu}$ alloys is directly related to silver. For the $\mathrm{Ag}_{99.84} \mathrm{Ti}_{0.16}$ liquid the $\mathrm{Ti}$ activity coefficient was about 80. What this work did not emphasize was the effect of copper on the titanium activity coefficient. Contrary to silver, which dramatically enhances the activity of titanium, an introduction of copper decreases this parameter. For instance, in an $\mathrm{Ag}_{83.57} \mathrm{Cu}_{15.76} \mathrm{Ti}_{0.67}$ liquid the activity coefficient was 4 times smaller than in $\mathrm{Ag}_{99.84} \mathrm{Ti}_{0.16}$, i.e. $\gamma_{\mathrm{Ti}}=20$, while for $\mathrm{Ag}_{59.1} \mathrm{Cu}_{39} \mathrm{Ti}_{1.9}$ this value was again 4 times lower. The reason for this dramatic decrease of the titanium activity coefficient, $80 \rightarrow 20 \rightarrow 5$, is connected, not so much with the decrease of the silver concentration in the melt, $99.84 \rightarrow 83.57 \rightarrow 59.1$, as emphasized by Pak et al., but rather with the increase of the copper content in the alloy: $0 \rightarrow 15.76 \rightarrow 39$. This effect could easily be explained by the high affinity of $\mathrm{Ti}$ to $\mathrm{Cu}$ and preferred $\mathrm{Cu}$-Ti pairing in the liquid. Earlier, Paulasto and Kivilahti also pointed out that the strong attractive interaction between $\mathrm{Cu}$ and $\mathrm{Ti}$ lowers the activity of Ti in Ag-Cu-Ti liquids [39].

Returning to the phase analysis of CB4, we come to the next observation. When we move up in temperature from the solidus point along the liquid composition path (Fig. 2) we observe a tendency towards an increase of the $\mathrm{Ag}: \mathrm{Cu}$ ratio, i.e. a deviation from the near-eutectic composition in the Ag-rich direction. The amount of $\mathrm{Ag}$ in the melt increases with the consumption of $\mathrm{Ag}[\mathrm{Cu}]$ phase until all the $\mathrm{Ag}[\mathrm{Cu}]$ phase is gone at $852{ }^{\circ} \mathrm{C}$. Since the activity of $\mathrm{Ti}$ is stimulated by $\mathrm{Ag}$ and depressed with $\mathrm{Cu}$, an increase in temperature would cause the activity coefficient of titanium $\gamma_{\mathrm{Ti}}$ to increase. This process coincides with an increase of the Ti concentration in the liquid $\left(X_{\mathrm{Ti}}\right)$. The multiplication of these two increasing parameters would produce a quicker increase (or "acceleration") of the Ti activity: $a_{\mathrm{Ti}}=\gamma_{\mathrm{Ti}} X_{\mathrm{Ti}}$. We would probably not make a big mistake if we assume that $a_{\mathrm{Ti}}=0.08$ at $852{ }^{\circ} \mathrm{C}$. At this point $90 \%$ of the alloy is melted and we have to conclude that the activity of titanium is high and thus has to play a crucial role in the brazing process.

Now, let us see how the activity of $\mathrm{Ti}$ is influenced by the segregating action in the liquid. At $874{ }^{\circ} \mathrm{C}$ a small part of the remaining $\mathrm{Cu}_{4} \mathrm{Ti}_{3}$ melts, causing an increase of $X_{\mathrm{Ti}}$ from 1.4 to 1.8 . The $\mathrm{Ag}: \mathrm{Cu}$ ratio of the liquid decreases, and so does $\gamma_{\mathrm{Ti}}$. The activity of titanium, $a_{\mathrm{Ti}}=\gamma_{\mathrm{Ti}} \cdot X_{\mathrm{Ti}}$ probably does not decrease, but remains nearly the same or increases insignificantly. At this point the composition of the liquid has reached the edge of the miscibility gap (Fig. 2). Further increase in temperature would melt the remaining $\mathrm{Cu}_{4} \mathrm{Ti}_{3}$ with the formation of $\mathrm{CuTi}$-rich liquid $\mathrm{L}_{2}$, which is immiscible with the liquid already present $\left(\mathrm{L} \rightarrow \mathrm{L}_{1}\right)$. With the formation of $\mathrm{L}_{2}$ there has to be some mutual diffusion of elements causing the $\mathrm{Ag}: \mathrm{Cu}$ ratio in $\mathrm{L}_{1}$ to increase with temperature (Fig. 2). This, in turn, has to enhance the titanium activity coefficient $\gamma_{\mathrm{Ti}}\left(\mathrm{L}_{1}\right)$, bringing the activity of Ti to even higher values, for instance to $a_{\mathrm{Ti}}=0.1$.

The second liquid, $\mathrm{L}_{2}$, is indeed rich in $\mathrm{Ti}$, $X_{\mathrm{Ti}}\left(\mathrm{L}_{2}\right)=0.307$ (mole fraction), but this high value does not mean high activity of titanium, as usually considered. $\mathrm{L}_{2}$ is also very rich in $\mathrm{Cu}$, $X_{\mathrm{Cu}}\left(\mathrm{L}_{2}\right)=0.626$, which suppresses the activity of Ti. Also, this liquid is low in the "titanium enhancer", i.e. Ag: $X_{\mathrm{Ag}}\left(\mathrm{L}_{2}\right)=0.067$. Thus, the activity of $\mathrm{Ti}$ in $\mathrm{L}_{2}$ and the reactive ability of this liquid have to be lower than expected.

In fact, since these two liquids are in equilibrium with each other, the chemical potential of titanium and its activity in both liquids has to be equal:

$$
\begin{aligned}
\mu_{\mathrm{Ti}}\left(\mathrm{L}_{1}\right) & =\mu_{\mathrm{Ti}}\left(\mathrm{L}_{2}\right), \\
a_{\mathrm{Ti}}\left(\mathrm{L}_{1}\right) & =a_{\mathrm{Ti}}\left(\mathrm{L}_{2}\right), \\
\gamma_{\mathrm{Ti}}\left(\mathrm{L}_{1}\right) \cdot X_{\mathrm{Ti}}\left(\mathrm{L}_{1}\right) & =\gamma_{\mathrm{Ti}}\left(\mathrm{L}_{2}\right) \cdot X_{\mathrm{Ti}}\left(\mathrm{L}_{2}\right) .
\end{aligned}
$$

From the last relationship it can be deduced that $\gamma_{\mathrm{Ti}}\left(\mathrm{L}_{2}\right)$ should be about 0.3 , which seems a reasonable number.

Consequently, the reactivities of $\mathrm{L}_{1}$ and $\mathrm{L}_{2}$, which are based on the activities of titanium, and the wetting/spreading abilities of these liquids during brazing processes, have to be identical, while the concentrations of the elements could be very different. We suppose that the above discussion should be sufficient to disprove the following erroneous beliefs [39-41]:

1) the Ag-rich liquid $L_{1}$ does not play an active role in the brazing processes,

2) only the Ti-rich liquid $L_{2}$ is responsible for the reactive behavior of $\mathrm{Ag}-\mathrm{Cu}-\mathrm{Ti}$ braze alloys, and 3) the liquid segregation, which produces a Ti-rich phase, is crucial for the reactive abilities of Ag-Cu-Ti braze alloys.

\section{Differences between $L_{1}$ and $L_{2}$}

The difference between $\mathrm{L}_{1}$ and $\mathrm{L}_{2}$ is not in their reactivity but in the ability to sustain this reactivity, should the brazing process be Ti-consuming. Note that titanium is usually needed only for the wetting and 
spreading. During the cooling procedure any excessive Ti would turn into brittle intermetallics, which are detrimental for the mechanical properties of the braze joint. In this sense $\mathrm{L}_{1}$ has a great advantage since it is equally surface active, but produces only a small amount of intermetallics. The role of $\mathrm{L}_{2}$, if there is any, is a buffer storage for $\mathrm{Ti}$ in case it is actively consumed by surface reactions, for instance with oxide or nitride ceramics. In case of $\mathrm{CB} 4$, the amount of $L_{2}$ is low (13 at.\%), which means that this liquid alone could not provide the conditions necessary for sound and uniform brazing, since this process is characterized by a high surface-to-volume ratio.

Another significant difference between the segregated $\mathrm{L}_{1}$ and $\mathrm{L}_{2}$ is the difference in their densities, which causes a gravimetric effect. The densities of pure solid $\mathrm{Ag}, \mathrm{Cu}$ and $\mathrm{Ti}$ at room temperature are $10.5,9.0$ and $4.5 \mathrm{~g} / \mathrm{cm}^{3}$, respectively, reflecting the differences between their atomic radii (volumes) and atomic weights. We estimate that the density and the volumetric ratios of the segregated liquids $\mathrm{L}_{1}\left(\mathrm{Ag}_{65.0} \mathrm{Cu}_{33.2} \mathrm{Ti}_{1.8}\right)$ and $\mathrm{L}_{2}\left(\mathrm{Ag}_{6.7} \mathrm{Cu}_{62.6} \mathrm{Ti}_{30.7}\right)$ are about

$$
\begin{gathered}
\rho\left(\mathrm{L}_{1}\right): \rho\left(\mathrm{L}_{2}\right) \approx 1.35, \\
V_{1}: V_{2} \approx 88: 12 .
\end{gathered}
$$

The difference in density between $\mathrm{L}_{1}$ and $\mathrm{L}_{2}$ was noticed by Paulasto et al. in their experiments when they noticed that the lighter liquid $\mathrm{L}_{2}$ rose to the surface of the melt [23].

\section{Driving forces}

After the above discussion, it becomes clear that there are two major forces during the brazing processes, which incorporate segregated reactive brazing melts. One Archimedean, which drives the titanium-rich, lighter liquid $\mathrm{L}_{2}$ upwards and the other Fickian, which tends to equilibrate the chemical potentials of titanium in the different phases. Should titanium be consumed in the reaction layer at the (base metal)-(liquid) interface, as is usually the case in reactive brazing, the chemical (Fickian) driving force would be directed from the bulk to the interfaces, i.e. either upwards or downwards. The picture could be distorted and confused with Brownian movement of atoms in the liquids and with surface tension forces that might affect the spatial distribution of the segregated liquids close to the surfaces to be joined. Since the interfaces in the samples are positioned horizontally (to prevent both splitting of the pieces and the loss of brazing alloy) the upper and lower interfaces become asymmetric with respect to the segregated liquids and thus the concentration of titanium (not the activity!) should be shifted towards the upper interface, provided the gravimetric and diffusional factors are dominating.

Now, let us comment on the surface tension, which might affect the redistribution of elements in the liquid since the system, which in our case is a sandwich-like sample, would try to attain the lowest possible surface energy. When the braze alloy wets the surfaces of the brazed parts, the only liquid surface exposed to the furnace atmosphere is the meniscus that circles around near the edges of the coin-like samples. It is expected that the composition of the free surface of the liquid will differ from the stoichiometry of the bulk, like it happens in binary $\mathrm{Ag}-\mathrm{Cu}$ liquids when silver segregates to the surface [11].

We do not have any data on Ag-Cu-Ti liquids, but the segregating tendencies should be very similar to the $\mathrm{Ag}-\mathrm{Cu}-\mathrm{Zr}$ system analyzed by Novakovic et al. $[42,43]$. The surface tension of the pure elements increases in the row $\mathrm{Ag} \rightarrow \mathrm{Cu} \rightarrow \mathrm{Zr}(\mathrm{Ti})$. In the binary alloys $\mathrm{Ag}-\mathrm{Cu}, \mathrm{Ag}-\mathrm{Zr}$ and $\mathrm{Cu}-\mathrm{Zr}$, the element with lower surface tension will segregate to the surface, thus lowering the surface energy of the system $[11,42,43]$. It is easy to conclude that in the ternary Ag-Cu-Ti system, the tendency for segregation would be most pronounced for $\mathrm{Ag}$ and less for $\mathrm{Cu}$, driving the $\mathrm{Cu}$-Ti-rich $\mathrm{L}_{2}$ away from the free surface of the liquid and creating a radial force that would keep $\mathrm{Ti}$ inside the filler alloy while pushing Ag to the edges.

Note that the melting points of the pure elements increase in the row $\mathrm{Ag} \rightarrow \mathrm{Cu} \rightarrow \mathrm{Ti}$ and, consequently, the vapor pressures of the elements will increase in the opposite direction, $p_{\mathrm{Ti}} \rightarrow p_{\mathrm{Cu}} \rightarrow p_{\mathrm{Ag}}$. Under high vacuum conditions, segregation of silver would support its vaporization and loss by the liquid. The loss of Ag-rich liquid $\mathrm{L}_{1}$ was observed by Shiue et al. during brazing studies with Ag-Cu-Ti filler metals [33], but it is hard to say if the loss of $\mathrm{L}_{1}$ was caused solely by the segregating action, or by another reason like the brazing technique or geometry of the samples. In any case, in the brazing process surface tension is important not only for wetting and spreading, but also for the segregating action on the free liquid surface and should thus be taken into consideration.

Finally, we have to mention that all the above phase analysis was made based on very few experimental studies and thermodynamic estimates considering equilibrium conditions. The brazing process, however, is not an equilibrium one but should be viewed as dynamic since the temperature, the compositions and the densities of the phases, the bond distribution, the activities of the elements and the surface tension between the phases - they all change in time. Still, we hope that some of our conclusions are important in understanding the transformations that occur during the brazing processes involving Ag-Cu-Ti filler alloys.

\section{Conclusions}

1. The phase transformations during heating-cooling of the Ag70.5Cu26.5Ti3 filler alloy known as CB4 are described based on the ternary $\mathrm{Ag}-\mathrm{Cu}-\mathrm{Ti}$ phase diagram. The liquid segregation paths and the liquid composition path are constructed for CB4 and the liquid evolution and the concentration of $\mathrm{Ti}$ in the liquid are plotted versus temperature. The apparent 
discrepancies between the liquidus and solidus points published in the literature and estimated from the phase diagrams are discussed.

2. It is established that at $808{ }^{\circ} \mathrm{C}$ the majority of the filler alloy is melted and the Ti activity in this liquid is high.

3. With an increase of temperature the following changes could be noted:

$>$ the composition of the remaining solid $\mathrm{Cu}-\mathrm{Ti}$ intermetallic phase changes $\mathrm{Cu}[\mathrm{Ag}, \mathrm{Ti}] \rightarrow \mathrm{Cu}_{4} \mathrm{Ti} \rightarrow \mathrm{Cu}_{3} \mathrm{Ti}_{2} \rightarrow \mathrm{Cu}_{4} \mathrm{Ti}_{3}$,

$>$ the amount of $\mathrm{Ag}[\mathrm{Cu}]$ phase decreases,

$>$ the composition of the liquid shifts towards higher $\mathrm{Ag}: \mathrm{Cu}$ ratios,

$>$ the concentration of $\mathrm{Ti}$ in the liquid increases,

$>$ the Ti activity coefficient also increases,

$>$ the activity of $\mathrm{Ti}$ (and its chemical potential) in the liquid accelerates and is sufficient for reactive brazing before the alloy is completely melted and liquid is segregated.

4. In the Ag-Cu-Ti liquid, $\mathrm{Cu}$ suppresses the $\mathrm{Ti}$ activity, contrary to $\mathrm{Ag}$, which enhances it.

5. The activities of $\mathrm{Ti}$ in both segregated liquids are identical, though the concentrations are very different. Both liquids, the $\mathrm{Ag}$-rich $\mathrm{L}_{1}$ and the $\mathrm{Cu}$-Ti-rich $\mathrm{L}_{2}$, are equally reactive, not just $\mathrm{L}_{2}$, as often believed. The segregating action in the liquid is actually not a necessary condition for reactive brazing.

6. The major differences between $\mathrm{L}_{1}$ and $\mathrm{L}_{2}$ are the following

$>\mathrm{L}_{2}$ works as a $\mathrm{Ti}$ storage and supplier if $\mathrm{Ti}$ is excessively consumed during the reactive brazing process,

$>\mathrm{L}_{2}$ produces significant amounts of intermetallic compounds, which are brittle and detrimental for the mechanical properties of the braze joints,

$>\mathrm{L}_{1}$ is heavier than $\mathrm{L}_{2}$ by ca. $35 \%$, which results in significant Archimedean forces tending to make the two interfaces (upper and lower) asymmetric.

7. The surface tension of the free liquid surface is lowered with preferential segregation of $\mathrm{Ag}$ and depletion of $\mathrm{Ti}$. This segregation creates a radial force that for $\mathrm{Ti}$ would be centripetal, while for $\mathrm{Ag}$ centrifugal, i.e. supportive for storing $\mathrm{Ti}$ and for losing Ag.

\section{References}

[1] M.M. Schwartz, Fundamentals of brazing, In: ASM Handbook, Vol. 6: Welding, brazing, and soldering, ASM International, Materials Park, OH, 1993, pp. 114-125.

[2] S.D. Brandi, S. Liu, J.E. Indacochea, R. Xu, Brazeability and solderability of engineering materials, In: ASM Handbook, Vol. 6: Welding, brazing, and soldering, ASM International, Materials Park, OH, 1993, pp. 617-637.

[3] R.I. Batista, Brazing of refractory and reactive metals, In: ASM Handbook, Vol. 6: Welding, brazing, and soldering, ASM International, Materials Park, OH, 1993, pp. 941-947.

[4] A.J. Moorhead, W.H. Elliott, H.E. Kim, Brazing of ceramic and ceramic-to-metal joints, In: ASM Handbook, Vol. 6: Welding, brazing, and soldering, ASM International, Materials Park, OH, 1993, pp. 948-960.

[5] H. Mizuhara, K. Mally, Weld. J. 64 (1985) 27-32.

[6] R. Xu, J.E. Indacochea, J. Mater. Sci. 29 (1994) 6287-6294.

[7] R. Xu, J.E. Indacochea, J. Mater. Eng. Perform. 3 (1994) 596-605.

[8] J.E. Indacochea, S. Hirnyj, M. Al-Nagy, Reactive braze ceramic-metal joining, In: J.E. Indacochea (Ed.), Proc. Inter-University Research Workshop "Joining of Advanced Engineering Materials", UIC, Chicago, IL, 1996, pp. 142-160.

[9] S. Hirnyj, J.E. Indacochea, M. Al-Nagy, Coll. Abstr. X Int. Conf. Crystal Chem. Intermet. Compd., Lviv, 2007, p. 13.

[10] T.B. Massaski (Ed.), Binary Alloy Phase Diagrams, $2^{\text {nd }}$ Ed., ASM International, Materials Park, OH, 1990.

[11] R. Novakovic, E. Ricci, D. Giuranno, A. Passerone, Surf. Sci. 576 (2005) 175-187.

[12] K.C.H. Kumar, I. Ansara, P. Wollants, L. Delaey, Z. Metallkd. 87 (1996) 666-672.

[13] J.J. Pak, M.L. Santella, R.J. Fruehan. Metall. Trans. B 21(2) (1990) 349-355.

[14] F.R. de Boer, R. Boom, W.C.M. Matterns, A.R. Miedema, A.K. Nielssen, Cohesion in Metals, North-Holland, Amsterdam, 1988.

[15] G. Effenberg, S. Ilyenko (Eds.), Noble Metal Ternary Systems: Phase Diagrams, Crystallographic and Thermodynamic Data, Vol. 11B: Noble Metal Systems, Selected Systems from Ag-Al-Zn to Rh-Ru-Sc, Springer, BerlinHeidelberg, 2006, pp. 1-12.

[16] V.N. Eremenko, Y.I. Buyanov, N.M. Panchenko, Porosh. Metall. 10(4) (1970) 44-48.

[17] Metals Handbook, $8^{\text {th }} \quad$ Ed., Vol. 8: Metallography, Structures and Phase Diagrams, ASM, Metals Park, OH, 1973.

[18] R. Hultgren, P.D. Desai, D.T. Hawkins, M. Gleiser, K.K. Kelly, Selected Values of the Thermodynamic Properties of Binary Alloys, ASM International, Metals Park, OH, 1973, p. 44.

[19] Y.A. Chang, D. Goldberg, J.P. Neumann, J. Phys. Chem. Ref. Data 6(3) (1977) 621-669.

[20] J.L. Murray, K.J. Bhansali, Bull. Alloy Phase Diagrams 4 (1983) 178-182.

[21] J.L. Murray, Phase Diagrams of Binary Titanium Alloys, ASM International, Metals Park, $\mathrm{OH}$, 1987.

[22] J.K. Kivilahti, F.J.J. van Loo, Mater. Sci. Forum 126-128 (1993) 209-212.

[23] M. Paulasto, F.J.J. Van Loo, J.K. Kivilahti. J. Alloys Compd. 220 (1995) 136-141. 
[24] H. Okamoto, J. Phase Equilib. 26(3) (2002) 549-550.

[25] E. Raub, P. Walter, M. Engel, Z. Metallkd. 43 (1952) 112-118.

[26] N. Karlsson, J. Inst. Met. 79 (1951) 391-405.

[27] P. Canale, C. Servant, Z. Metallkd. 93 (2002) 273-276.

[28] J.Y. Brun, S.J. Hamar Thibault, C.H. Allibert, Z. Metallkd. 74 (1983) 525-529.

[29] V.N. Eremenko, Y.I. Buyanov, S.B. Prima, Porosh. Metall. 6(6) (1966) 77-85.

[30] V.N. Eremenko, Y.I. Buyanov, N.M. Panchenko, Porosh. Metall. 10(5) (1970) 73-78.

[31] R. Arroyave, Ph.D. Thesis, MIT, 2004.

[32] R. Arroyave, T.W. Eagar, L. Kaufman, J. Alloys Compd. 351 (2003) 158-170.

[33] R.K. Shiue, S.K. Wu, C.H. Chan, J. Alloys Compd. 372 (2004) 148-157.

[34] V.N. Eremenko, Y.I. Buyanov, N.M. Panchenko, Izv. Akad. Nauk SSSR, Metally (3) (1969) 190-192.

[35] V.N. Eremenko, Y.I. Buyanov, N.M. Panchenko. Izv. Akad. Nauk SSSR, Metally (5) (1969) 200-202.
[36] O. Kubaschewski, Silver-Copper-Titanium, In: G. Petzow, G. Effenberg (Eds.), Ternary Alloys: a comprehensive compendium of evaluated constitutional data and phase diagrams, Vol. 2, VCH, Weinheim, 1988, pp. 55-59.

[37] P. Villars, A. Prince, H. Okamoto, Handbook of Ternary Alloy Phase Diagrams, ASM International, Materials Park, OH, 1996, pp. 2353-2360.

[38] R. Arroyave, T.W. Eagar, TMS Lett. 1 (2004) 8788.

[39] M. Paulasto, J.K. Kivilahti, Scr. Metall. Mater. 32 (1995) 1209-1214.

[40] M. Paulasto, J.K. Kivilahti, J. Mater. Res. 13 (1998) 343-352.

[41] R.K. Shiue, S.K. Wu, J.M. O, J.Y. Wang, Metall. Mater. Trans. A 31 (2000) 2527-2536.

[42] R. Novakovic, M.L. Muolo, E. Ricci, E. Ferrera, D. Giuranno, F. Gnecco, A. Passerone, Mater. Sci. Forum 512 (2006) 211-216.

[43] R. Novakovic, M.L. Muolo, A. Passerone, Surf. Sci. 549 (2004) 281-293. 